\section{Chernobyl fire chronology}

\section{Moscow} after its No. 2 power unit's fourth turbogenerator had been shut down for scheduled repairs, fire once again swept through the Chernobyl Nuclear Power Plant (NPP). Operators had accidentally connected the generator to the plant's power network, forcing powerful currents through its wiring and igniting its insulation.

Sixty seconds later, at 8:10 p.m., the NPP's operator pushed the emergency button in a bid to shut off the No. 2 power unit's reactor. Oil was vented from the turbo-generator and operators began substituting hydrogen inside the reactor with nitrogen, in a fruitless attempt to check the spread of the fire. Special seals leading into the generator had apparently broken when the insulation caught fire. As a result, hydrogen escaped from the unit, subsequently catching fire and exploding. The engine room's roof started burning, and, according to the late reports, four roof girders caved in.

Automatic fire extinguishers then activated, and fire-fighters arrived at the scene some time later, putting out the fire by is now being cooled off. hours' time.
ON 11 October at 8:09 p.m., 20 minutes

11:30 p.m. The No. 2 power unit's reactor

Experts voiced reassuring statements during a news conference in Kiev last week, saying that there were no fatalities and that no radiation had spewed into the atmosphere. Only the engine room proper has been damaged, they added. However, the accident has entailed considerable losses, including the halting of the damaged power unit. The precise causes of the accident are now being verified.

Curiously enough, the Trud newspaper carried an interview with Victor Bryukhanov, who headed the Chernobyl NPP prior to the April 1986 disaster, on September 17. It was headlined "The Chernobyl NPP Must Be Stopped Completely". This was Bryukhanov's first interview upon his release from prison. He was been sentenced to 10 years in prison during the Chernobyl trial, but has just returned home after serving half of his term in a medium-security labour camp. Until earlier this year, he was engaged in corrective labour at a place not far from Kiev that can be reached by car in three

Yuri Kanin

\section{SOVIET SCIENCE}

\section{Russia takes over academy}

\section{Moscow}

IN science, like nearly every other aspect of Soviet life, last August's attempted coup has become a catalyst for radical change and disintegration. As institutions fall, even the country's supreme scientific organization - the USSR Academy of Sciences - has not remained immune.

At the Academy's general meeting last month, academy members voted 160 to ten to "return to the USSR Academy of Sciences the status of the Russian Academy of Science." This will put the Academy and its research institutes under Russian jurisdiction, although just what the Academy will consist of in the future is an open question. Russia has just created its own Academy of Sciences, and is unlikely to split its scarce funding two ways. Another major Soviet scientific structure, the USSR State Committee for Science and Technology, has also transfer to Russia. According to Vladimir Shoron, chairman of the Russian Supreme Soviet Committee for Science and Public Education, the Russian Council of Ministers decided on 8 October to take the science and technology committee under its wing.

Russia is the largest Soviet republic, both in geographic area and in scientific potential. The majority of the 365 scientific institutions of the USSR Academy, are in Russia, as are 95 per cent of its members. And until recently, Russia was the only one of the newly-sovereign states which had no academy of its own. So in June 1990 - before anyone suspected that the USSR Academy might soon be put under Russian jurisdiction - the Russian Supreme Soviet decided to establish a Russian Academy. In March 1991 an organizing committee was set up to develop the charter and guidelines for the Academy. The newly-formed regional organizing committees have nominated candidates and will hold first elections for Academy membership in December.

Yet many questions still remain. Now there will be two academies in Russia: One of them, the Russian Academy, has no material base, institutions or laboratories, but has been promised relatively solid financial backing from the Russian government. The other, the now-Russian-controlled USSR Academy, has numerous institutions, but little political support. Its researcher cannot realistically hope for adequate funding. As USSR Academy researchers were told at the general meeting last month, the Academic institutions will have no hard currency to subscribe to foreign scientific publications in 1992. Rank-and-file research associates are paid less than janitors. And researchers are afraid that the USSR Academy will wither under Russian rule, something that is likely to only worsen the brain drain and exodus of gifted young scientists. Yuri Kanin

\section{Trouble at AFRC}

London

Agricultural research is the latest area of British science to fall victim to the economic recession. Tom Blundell, directorgeneral of the Agricultural and Food Research Council (AFRC), says that his organization faces a $£ 10$ million shortfall in the 1992-93 fiscal year. In large part, Blundell blames the collapse of the British property market, which has left AFRC unable to sell several large laboratories that were closed during the cutbacks and restructuring that preoccupied the council during the 1980s. In the context of AFRC's smaller budget (the council receives only about $\$ 90$ million a year from the Department of Education and Science), AFRC's plight is similar to that which has afflicted the Science and Engineering Research Council over the past year.

Blundell, who first revealed his council's problems in an interview with the Times Higher Education Supplement, says that AFRC had planned to receive some $£ 7$ million from the sale of its unused buildings and land next year. Most of this money was expected to come from the sale of the Houghton Laboratory in Cambridgeshire, a former base for AFRC's poultry research, or the Hurley Research Station in Berkshire, formerly part of AFRC's Institute of Grassland and Animal Production. Blundell had hoped that one of these laboratories would be bought by a company seeking new headquarters offices. But with most British business concentrating on survival, rather than relocation, no buyers have come forward.

Blundell says that AFRC is also faced with a bill for the pension funds of retired researchers from AFRC's former Institute of Horticultural Research. Although this institute has now been reconstituted as a separate agency, Horticultural Research International, linked to the UK agriculture ministry, an Act of Parliament is needed to transfer the pension fund from AFRC. With the government now concentrating on preparing for a general election, Blundell is concerned that the legislation may be delayed.

Blundell hopes that AFRC's finances can be eased by an infusion of new funds in the government's public expenditure settlement, due next month. But he says that many other public sector agencies also face problems selling their empty buildings, so the Treasury may be reluctant to compensate AFRC for much of the shortfall. If little extra money is found, the bulk of the necessary cuts must come in spending on equipment at AFRC's own institutes and in the council's support for university researchers. The cuts would temporarily reverse the council's long-term plan to increase by 50 per cent its spending in the universities, now running at just under $£ 20$ million a year. Peter Aldhous 